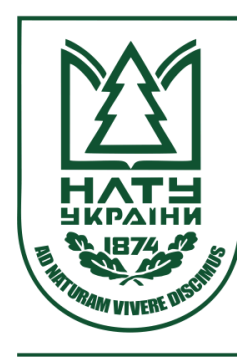

Науковий вісник НлтУ України Scientific Bulletin of UNFU

https://nv.nltu.edu.ua

https://doi.org/10.15421/40290519

$@ \bowtie$ Correspondence author

Article received 23.04.2019 p.

Article accepted 30.05.2019 p.

S. N. Kulman

УДК 674.048

sergiy.kulman@gmail.com

С. М. Кульман, Я. П. Бугаєнко, Л. М. Бойко, Й. В. Загурський

Житомирський національний агроекологічний університет, м. Житомир, Украӥна

\title{
ДОСЛІДЖЕННЯ ФЕНОМЕНУ ПОПЕРЕДНЬОГО НАПРУЖЕННЯ ДЕРЕВ'ЯНИХ КЛЕЄНИХ БАЛОК
}

\begin{abstract}
Упродовж багатьох років попередньо напружені клеєні балки успішно застосовують, наприклад, у будівництві як несучі конструкції. Метою дослідження поставлено розробку конструкції із зменшеною витратою матеріалів. Спосіб виготовлення полягає у склеюванні тонких попередньо зігнутих ламелей до потрібної висоти, після чого склеєний ламельний блок розрізають за висотою уздовж поздовжньої осі, а потім розрізані частини склеюють між собою своїми вигнутими сторонами (поверхнями). Метою експерименту було дослідити згинальну жорсткість прямолінійної балки, склеєної з вигнутих ламелей в разі, коли попередні напруження в ламелях відсутні, з випадком наявності таких напружень. Перший варіант навантаження полягав у створенні попередньо напруженого стану балки та у визначенні максимально нормальних напружень. 3'ясовано, що кожна з ламелей має під час їх вигину розтягнуті області у верхній частині з напругою розтягнення від $\mathrm{SX}=+65 \mathrm{MПа} \mathrm{до}$ $\mathrm{SX}=+30$ МПа і стиснені області в нижній частині з напругою стиснення від SX $=-30$ МПа до SX $=-80$ МПа. Другий варіант навантаження полягав у створенні робочого навантаження на верхню площину балки за відсутності попереднього напруження. Максимальний прогин становить URES $=43,47$ мм. Величини внутрішніх напружень при цьому знаходяться в межах від -82 МПа у стисненій зоні до +82 МПа в розтягнутій. Третій варіант навантаження складався в наявності як попереднього напруження, так і робочого навантаження. Максимальний прогин становив URES $=27,49$ мм. Величини внутрішніх напружень при цьому знаходяться в межах від $\mathrm{SX}=-27$ МПа у стисненій зоні до $\mathrm{SX}=+34,5$ МПа в розтягнутій. Результати обчислювальних експериментів свідчать про те, що, застосовуючи попередні навантаження, в напрямку, протилежному вигину від робочого навантаження, можемо компенсувати вплив робочого навантаження. Встановлено, що застосування феномену попереднього напруження дає змогу створювати конструкції прямолінійних клеєних дерев'яних балок зниженої матеріаломісткості, при цьому ефект підвищення несучої здатності дерев'яної балки буде обмежений межею міцності на стиск матеріалу, з якого ії̈ виготовлено.
\end{abstract}

Ключові слова: попереднє напруження; дерев'яні клеєні балки; армовані дерев'яні балки.

Вступ. Полегшена вага структур є одним із показників розвиненої цивілізації. Усі конструкції, зокрема транспортні засоби, будинки, будівлі, товари тощо, з кожним роком стають легшими, а попит на них збільшується. Легкі конструкції постійно привертають увагу інженерівбудівельників упродовж багатьох років. Однак полегшеність може призвести до руйнування конструкції (втрати стійкості конструкції), так само це може призвести до зниження жорсткості конструкції. Дослідження структурних проблем, пов'язаних зі стабільністю, в такий спосіб стали важливішими, ніж будь-коли.

Конструкції мінімально можливої ваги завжди привертали до себе тих, хто розробляє нові вироби або конструює деталі машин. Адже для їх створення можна застосувати менше матеріалу і в такий спосіб здешевити, а отже - конкурувати з аналогами. Особливу увагу до полегшених конструкцій почали проявляти в останні десятиліття з огляду на створення і початок частого використання нових типів технологій, названих адитивними.
Попередньо напружені конструкції протягом багатьох років успішно застосовують, наприклад, у будівництві у несучу балки. У дерев'яному житловому будівництві використовують як попередньо напружені прямолінійні балки, так і купольні дерев'яні конструкції, склеєні по радіусах із ламелей.

Відомий спосіб виготовлення клеєних дерев'яних балок містить склеєний за висотою пакет із горизонтально покладених дощок із зубчастим з'єднанням між ними, розташованими за довжиною балки, за винятком області, розміри якої визначені математичною залежністю (Bredikhin, 2006).

Відомий також спосіб виготовлення клеєних дерев'яних балок, що містить підготовку стрічок до склеювання, нанесення водостійких клейових прошарків 3 еластичного клею на основі резорцинових смол на пласті стрічок із канавками, формування пакетів та пресування балок (Emelianov, Tokmakov, 2008). При цьому, в процесі пресування балок, здійснюють додаткове ви-

Інформація про авторів:

Кульман Сергій Миколайович, канд. техн. наук, доцент, кафедра експлуатації лісових ресурсів.

Email: sergiy.kulman@gmail.com; https://orcid.org/0000-0001-5354-5985

Бугаєнко Ярослав Петрович, канд. техн. наук, доцент, кафедра експлуатації лісових ресурсів. Email: yaroslav195415@ukr.net

Бойко Людмила Миколаївна, канд. техн. наук, доцент, кафедра експлуатації лісових ресурсів. Email: Isdesign@ukr.net

Загурський Йосип Владиславович, зав. лабораторією, кафедра експлуатації лісових ресурсів. Email: sergiy.kulman@gmail.com

Цитування за ДстУ: Кульман С. М., Бугаєнко Я. П., Бойко Л. М., Загурський Й. В. Дослідження феномену попереднього напруження дерев'яних клеєних балок. Науковий вісник НЛтУ України. 2019, т. 29, №5. С. 97-102.

Citation APA: Kulman, S. N., Bugayenko, Ya. P., Boiko, L. N., \& Zagursky, I. V. (2019). The study of the phenomenon of prestressed glulam beams. Scientific Bulletin of UNFU, 29(5), 97-102. https://doi.org/10.15421/40290519 
сушування поверхневої зони балки, причому канавки мають форму вузьких компенсаційних пропилів та розташовані вздовж бічних крайок, а також у середині ширини на протилежній пласті стрічки. Недоліком відомих способів виготовлення клеєних дерев'яних балок $є$ : за заданої висоти січення - недостатня несуча здатність; за заданої несучої здатності - завищена висота перетину i, як наслідок, перевитрата матеріалу та зайва власна вага балки.

Відомий дерев'яний клеєний брус для виготовлення стінових панелей виконано із п'яти поздовжніх стінок внутрішніх коротких дощок 3 можливістю їх складання у панелі необхідних розмірів (Jogans, 2006). Полиці у таких конструкціях мають функцію ребер жорсткості та підвищують жорсткість і міцність бруса, проте діапазон застосування відомих брусів обмежений їх використанням тільки для виготовлення стінових панелей.

Відому дерев'яну балку, що містить зовнішні поздовжні стінки та внутрішні полиці-пластини, виконано 3 використанням маломіцних і високоміцних порід деревини (Kovalchuk, 1982).

Порівняно 3 іншими аналогами відома балка має більшу жорсткість, міцність і несучу здатність, проте характеризується неоднорідністю складових елементів, складністю будови, виготовлення і експлуатації, пов'язаних із необхідністю ретельного вибору сортів і порід деревини для різних елементів конструкції балки, і високою вартістю.

Відома дерев'яна клеєна ферма складається 3 поздовжньої багатошарової стінки та звивистої решітки 3 використанням дискретних елементів, зубчастих шипів і пазів (Grachev, 2003). Конструкція такої форми перенасичена складовими елементами, складна у виготовленні, не відрізняється високою міцністю і неекономічна.

Відома дерев'яна двотаврова балка містить зібрані 3 ламелей поздовжні стінки, що скріплюють їхні похилі ребра жорсткості (Schneider, 1965). Однак балка має обмежену сферу застосування, що зумовлено вузьким діапазоном іiі конструктивних і технологічних можливостей. Окрім цього, такі балки мають обмежений ресурс щодо їх жорсткості, міцності та несучої здатності. До того ж застосування листової фанери істотно погіршує експлуатаційні показники балки: надійність, працездатність та довговічність.

Відомий спосіб підвищення згинальної жорсткості дерев'яних балок за допомогою створення попереднього напруженого стану (попередньо напружені клеєні балки "pre-stressed glulam beams"). Наприклад, попередньо напружена дерев'яна балка містить склеєний пакет дощок, обойми, установлених на торцях по кінцях балки, i попередньо напружену арматуру, закріплену кінцями до обойм. Відмінність у тому, що з метою підвищення несучої здатності способом забезпечення довготривалого ефекту попереднього напруження, забезпечена дерелаксаційними вузлами, кожен з яких з'єднаний 3 кінцем арматури, а обойма забезпечена ребрами, при цьому в балці виконані пази з утворенням ступеня на іiі торцях, які розміщені між ребрами обойми дерелаксаційних вузлів (Nakashidze, 1986).

Окрім цього, попереднє напруження стиснення розтягнутої зони балки (нижня площина) може бути створено способом закріплення у цій зоні пресованої деревини, тоді як у зоні стиснення балки під дією робочого навантаження (верхня площина) встановлюються вкла- диші з гарантованим натягом. Отже, у верхній зоні балки створюється попереднє напруження розтягування, тоді як у нижній зоні - попереднє напруження стиснення (Anshari, Guan, \&Wang, 2017). Однак недоліком такої конструкції є її складність, отже підвищення трудовитрат на ії виготовлення.

Патент на гнуті, клеєні несучі балки з двох і більше ламелей Хетцер отримав у 1906 р. (Hetzer, 1906). Новизна полягала не в самій склеюваній деревині, а в додаванні просторових форм будівельної деталі методом згинання. Зігнутість склеєної балки створює в кожній 3 iii ламелей попередньо напружений стан. При цьому верхня половина кожної ламелі знаходиться у попередньо розтягнутому, а нижня - у попередньо стисненому стані. Склеювання ламелей між собою дає змогу зафіксувати ці стани ламелей. Такі балки часто застосовують під час будівництва мостів і купольних споруд. Однак вигнута форма балки обмежує іï технологічні можливості під час створення плоских поверхонь.

Виходячи $з$ аналізу останніх досліджень попередньо напружених дерев'яних балок, метою дослідження $є$ розроблення конструкції із зменшеною витратою матеріалів. Завданням дослідження було довести, що розроблена конструкція дійсно зможе виконувати ті ж функції, що і іï аналог за меншої витрати матеріалів.

Матеріал та методика дослідження. Під час вирішення поставленого завдання використовували такі методики дослідження: визначення і порівняння допустимих навантажень під час опори балок методами опору матеріалів; обчислювальний експеримент у середовищі SolidWorks Simulation методом кінцевих елементів (MKE).

Технічним завданням, на вирішення якої спрямовано пропонований спосіб, є підвищення несучої здатності балки за заданої висоти способом створення попередньо напруженого її стану, а також спрощення конструкції балки, та розширення іiї технологічних можливостей.

Технічний результат досягається тим, що спосіб виготовлення попередньо напруженої прямої дерев'яної балки полягає у склеюванні тонких попередньо зігнутих ламелей до необхідної висоти, після чого склеєний ламельний блок розрізають за висотою уздовж поздовжньої осі, а потім розрізані частини склеюють між собою своїми вигнутими сторонами (поверхнями).

Спосіб виготовлення подано на рис. 1. На рис. 2 наведено дві частини розрізаного за висотою блоку ламелей. На рис. 3 наведено пряму дерев'яну балку, що попередньо напружена після склеювання розрізаних частин між собою своїми вигнутими сторонами. На рис. 4 наведено окрему вигнуту ламель до склеювання, i так само епюру внутрішніх напружень. На рис. 5 зображено склеєний блок ламелей, епюру внутрішніх напружень в кожній з ламелей, і загальну епюру внутрішніх напружень у блоці з трьох ламелей. На рис. 6 наведено розрізані частини склесні ламельного блоку та епюри внутрішніх напружень у кожній з частин. На рис. 7 зображено склеєну пряму балку із загальною епюрою внутрішніх напружень, які створюють попередньо напружену конструкцію.

Спосіб здійснюють так: підготовлені плоскі ламелі 1, 2, 3, 4, 5, 6 згинають і склеюють між собою у пресі, i отримують балку зігнутої форми з габаритною висотою А. Після цього балку розрізають уздовж поздовжньої осі за висотою, і окремі частини 7 і 8 склеюють між со- 
бою їхніми вигнутими поверхнями 9, 10. Отримана пряма балка матиме висоту Б, меншу від висоти зігнутої балки А.

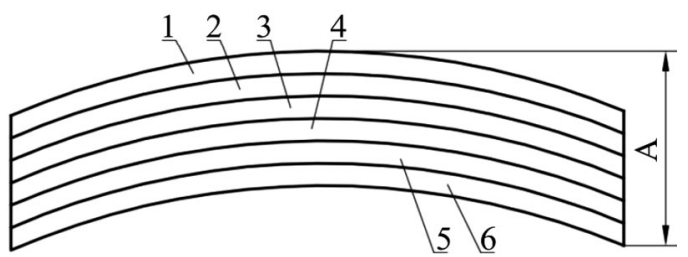

Рис. 1. Склеєний блок попередньо зігнутих ламелей

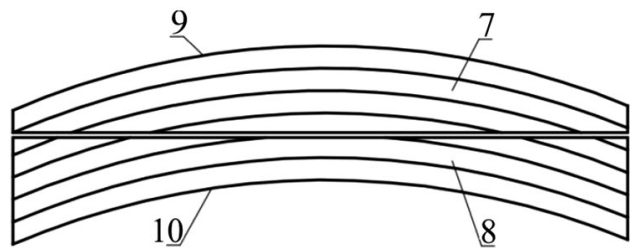

Рис. 2. Дві частини розрізаного за висотою блоку ламелей

8

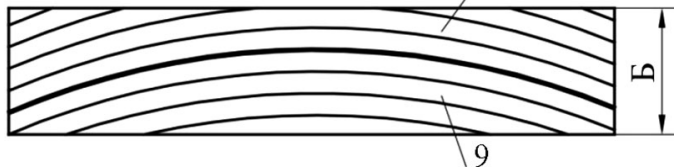

Рис. 3. Пряма дерев'яна балка, що попередньо напружена

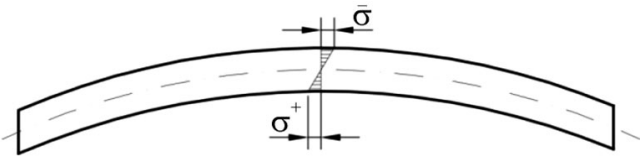

Рис. 4. Окрема вигнута ламель до склеювання і так само епюра внутрішніх напружень

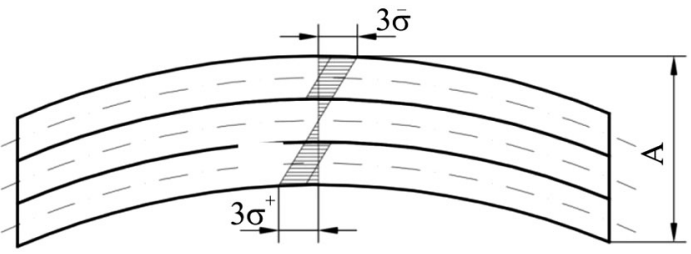

Рис. 5. Склеєний блок ламелей, епюра внутрішніх напружень в кожній $з$ ламелей, і загальна епюра внутрішніх напружень у блоці з трьох ламелей

Водночас ця балка матиме згинальну жорсткість, рівну згинальній жорсткості криволінійної балки. На рис. 4 наведено епюру внутрішніх напружень в одній плоскій попередньо зігнутій ламелі. При цьому верхня половина ламелі буде розтягнута, і буде мати внутрішні напруги, що дорівнюють величині $\sigma^{+}$, тоді як нижня половина буде стиснута і буде мати внутрішні напруги $\sigma^{-}$.

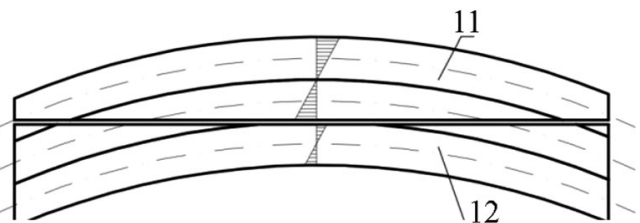

Рис. 6. Розрізані частини склеєні ламельного блоку і епюри внутрішніх напружень в кожній $з$ частин

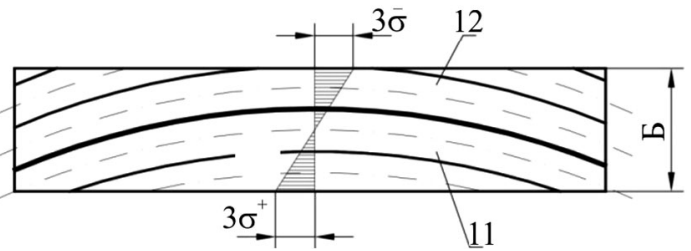

Рис. 7. Клеєна пряма балка із загальною епюрою внутрішніх напружень, які створюють попередньо напружену конструкцію

Після склеювання блоку 3, наприклад, трьох ламелей загальні внутрішні напруги розтягнення дорівнюватимуть $3 \sigma^{+}$, а внутрішня напруга стиснення $-3 \sigma^{-}$. Після розрізання вигнутого блоку на дві частини 11 та 12 і подальшого склеювання, балка набуде прямолінійної форми і буде мати загальні внутрішні напруги розтягнення $3 \sigma^{+}$i загальні внутрішні напруження стиску $3 \sigma^{-}$, як і вигнута склеєна балка. Однак висота прямої балки буде меншою.

Як досліджуваний об'єкт в обчислювальному експерименті приймали балку розміром $3000 \times 250 \times 60$ мм, склеєну з ламелей прямолінійної форми розміром $60 \times 40$ мм 3 матеріалу, механічні властивості якого представлено в табл. 1. Умови закріплення однакові, для різних варіантів додається навантаження. У термінології SolidWorks Simulation це зафіксована геометрія нижніх поперечних ребер. Їх показано на посиланні на модель у табл. 1. Тут же показане робоче навантаження у вигляді тиску на верхню площину балки в середині ії прольоту на одній третині довжини балки.

Табл. 1. Умови закріплення і властивості матеріалу

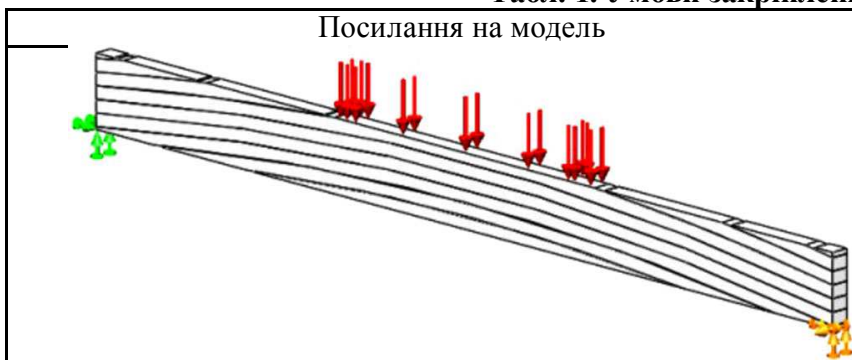

Сітку кінцевіх елементів моделі представлено на рис. 8. Метою експерименту було дослідити згинальну жорсткість прямолінійної балки, склеєної з вигнутих ламелей в разі, коли попередні напруження в ламелях відсутні, з випадком наявності таких напружень. Методична сітка обчислювальних експериментів містить три варіанти умов навантаження, що зазначено в табл. 2.

У кожному з варіантів розраховували такі величини (позначення згідно з програмою SolidWorks Simulation): Von Misec - еквівалентне напруження по Miзеса, MPa; $S X$ - нормальна напруга в поперечному перерізі під час

\begin{tabular}{c|c|c|}
\hline \multicolumn{2}{|c|}{ Властивості } \\
\hline \multirow{2}{*}{ Тип моделі: } & Лінійний, пружний, ізотропний \\
\cline { 2 - 3 } & Межа текучості & $1,12 \mathrm{E}+008 \mathrm{~N} / \mathrm{m}^{2}$ \\
\hline Масова щільність: & $600 \mathrm{~kg} / \mathrm{m}^{3}$ \\
\hline Модуль пружності: & $1,4 \mathrm{E}+010 \mathrm{~N} / \mathrm{m}^{2}$ \\
\hline & \\
Коефіцієнт Пуассона: & 0,394 \\
\hline
\end{tabular}

вигину, MPa; URES - переміщення в напрямку дії, результуючої навантаження, мм.

Рис. 8. Сітка кінцевих елементів моделі прямолінійної балки, склеєної з попередньо деформованих ламелей

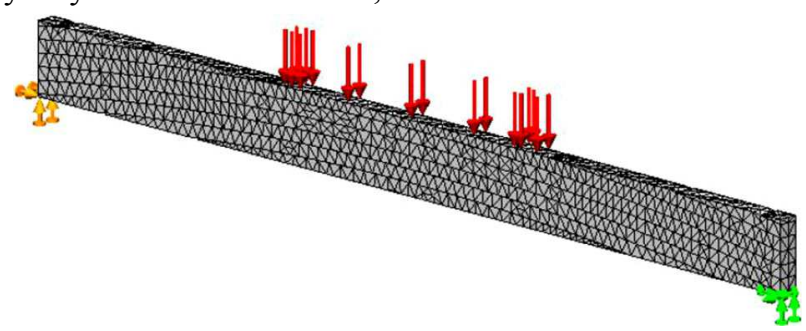


Результати й обговорення. Результати дослідження в середовищі SolidWorks Simulation представлено в табл. 2. Перший варіант навантаження полягав у створенні попередньо напруженого стану балки і визначенні максимальних еквівалентних і нормальних напружень.

Попередньо напружений стан ламелей у зігнутому і зафіксованому (склеєному) положеннях імітували способом розтягування верхніх шарів кожної з ламелей під час їх глобального контакту. Епюру нормальних напружень склеєної балки під дією попереднього напруження представлено на рис. 9. Як видно з цього рисунку, кожна $з$ ламелей має розтягнуті області у верхній частині 3 напругою розтягнення від $\mathrm{SX}=+65 \mathrm{MПа}$ до $\mathrm{SX}=$ +30 МПа і стислі області в нижній частині з напругою стиснення від $\mathrm{SX}=-30 \mathrm{MПа} \mathrm{до} \mathrm{SX}=-80 \mathrm{MПа.} \mathrm{Другий}$ варіант навантаження полягав у створенні робочого навантаження на верхню площину балки за відсутності попереднього напруження. Епюру переміщень цього варіанта зображено на рис. 10. Як бачимо, максимальний прогин у середині балки становив URES = 43,47 мм.

Епюру нормальних напружень під час згинання балки представлено на рис. 11. Величини внутрішніх нап- ружень при цьому знаходяться в межах від -82 МПа у стислій зоні до +82 МПа у розтягнутій.

Третій варіант навантаження складався за наявності як попереднього напруження, так і робочого навантаження. На рис. 12 зображено епюру переміщень для цього варіанта. Максимальний прогин у середині балки становив URES $=27,49$ мм.

Епюру нормальних напружень під час згину балки в разі наявності попередньо напружених представлено на рис. 13. Величини внутрішніх напружень при цьому знаходяться в межах від $\mathrm{SX}=-27$ МПа у стислій зоні до $\mathrm{SX}=+34,5$ МПа у розтягнутій.

Результати обчислювальних експериментів свідчать про те, що, застосовуючи попереднє навантаження, згинаючи ламель в напрямку, протилежному вигину від робочого навантаження, можемо компенсувати вплив робочого навантаження, а отже - підвищувати згинальну жорсткість клеєної дерев'яної балки. Використання способу забезпечення підвищення несучої здатності прямолінійної балки прямокутного січення за заданої висоти дасть змогу розширити технологічні можливості та спростити конструкцію балки.

Табл. 2. Методична сітка дослідів та результати симуляційних досліджень

\begin{tabular}{|c|c|c|c|c|c|c|c|}
\hline \multirow{3}{*}{ № 3/ח } & \multicolumn{3}{|c|}{ Умови навантаження } & \multicolumn{4}{|c|}{ Результати експерименту } \\
\hline & \multicolumn{2}{|c|}{$\begin{array}{c}\text { середні попередні напруження } \\
\text { в кожній з ламелей, МПа }\end{array}$} & \multirow{2}{*}{$\begin{array}{c}\text { робоче наван- } \\
\text { таження, } \\
\text { МПа }\end{array}$} & \multicolumn{2}{|c|}{$\begin{array}{l}\text { максимально нормальні напру- } \\
\text { ження під час згину (SX), MПа }\end{array}$} & \multirow{2}{*}{$\begin{array}{c}\text { максимальний } \\
\text { прогин (URES), } \\
\text { мм }\end{array}$} & \multirow{2}{*}{$\begin{array}{c}\text { еквівалентні напруги } \\
\text { по Мизесу } \\
\text { (Von Misec), МПа }\end{array}$} \\
\hline & $\begin{array}{c}\text { У зоні } \\
\text { розтягування }\end{array}$ & $\begin{array}{c}\text { У зоні } \\
\text { стиснення }\end{array}$ & & розтягування & стиснення & & \\
\hline 1 & 47,5 & -55 & 0 & 47,5 & -55 & - & 90 \\
\hline 2 & 0 & 0 & 2 & 82 & -82 & 43,47 & 108 \\
\hline 3 & 47,5 & -55 & 2 & 34,5 & -27 & 27,49 & 18 \\
\hline
\end{tabular}

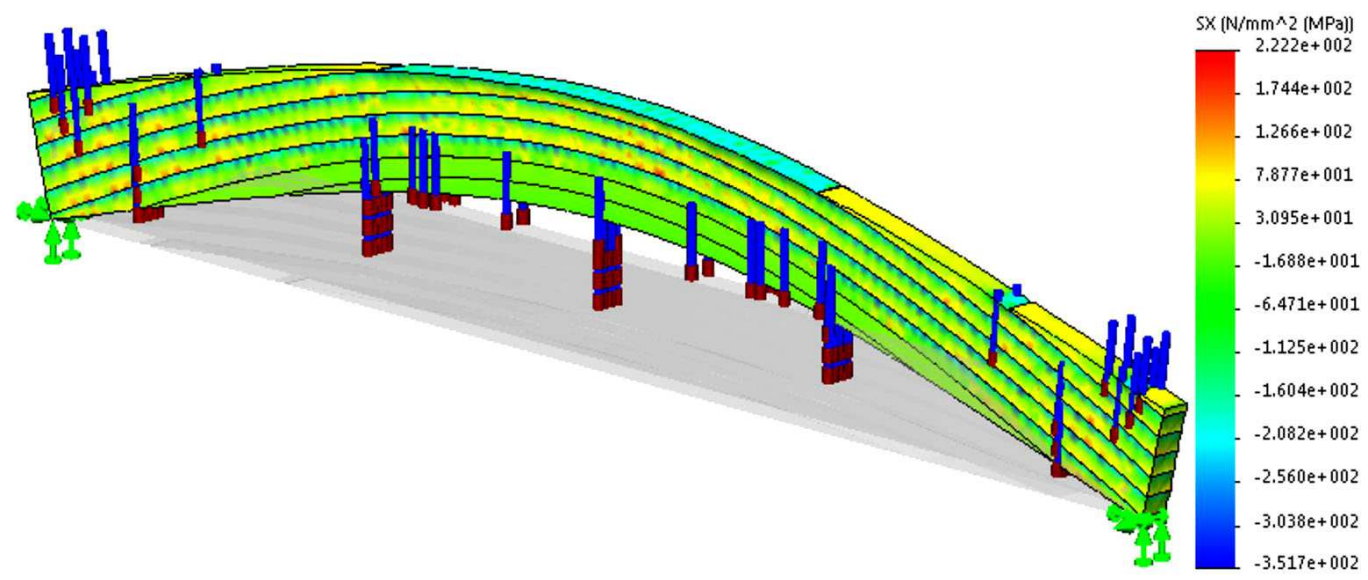

Рис. 9. Епюра попередньо створених нормальних напружень в кожній з ламелей балки

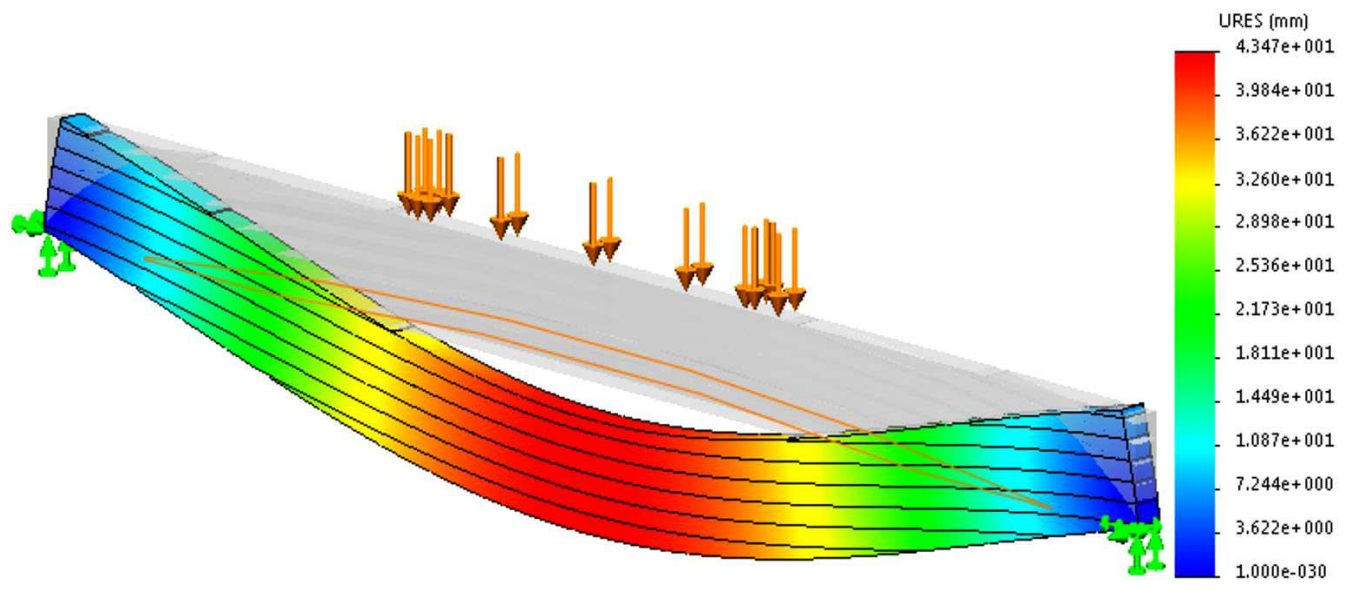

Рис. 10. Епюра переміщень балки без попереднього напруження в напрямку згинального навантаження 


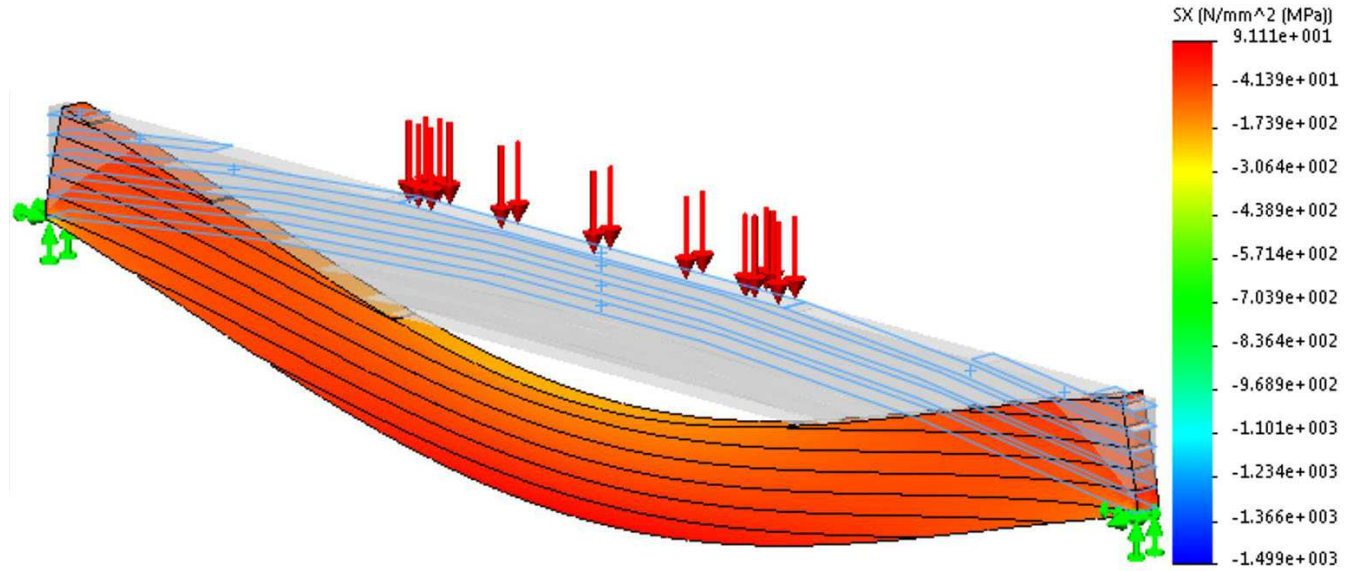

Рис. 11. Епюра нормальних напружень у балці без попереднього напруження

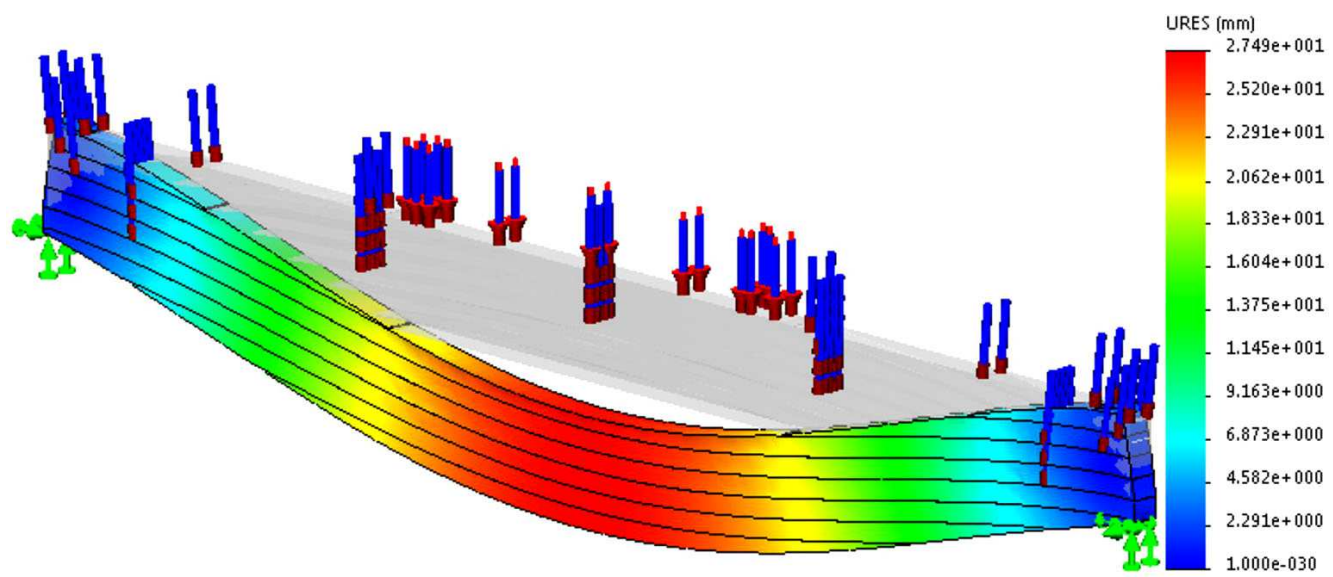

Рис. 12. Епюра переміщень попередньо напруженої балки в напрямку згинального навантаження

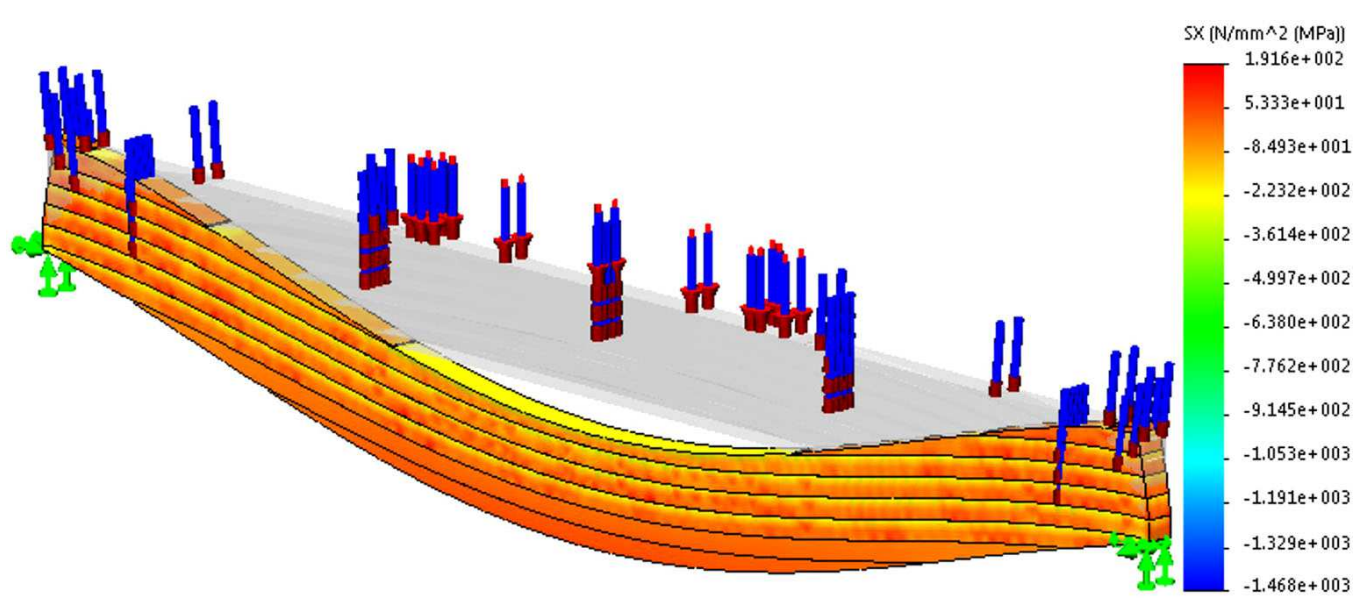

Рис. 13. Епюра нормальних напружень у балці попереднього напруження

Висновки. На основі аналізу отриманих результатів симуляційного моделювання можна зробити такі висновки:

1. Застосування феномену попередньої напруги дає змогу створювати конструкції прямолінійних клеєних дерев'яних балок зниженої матеріаломісткості.

2. При цьому ефект підвищення несучої здатності дерев'яної балки буде обмежений межею міцності на стиск матеріалу, з якого її виготовлено.

3. Для отримання більш точних значень збільшення коефіцієнта підвищення несучої здатності пропонованої конструкції дерев'яної балки планують провести натурні експерименти на спеціальному програмно-апаратному комплексі лабораторії механічних випробувань кафедри експлуатації лісових ресурсів ЖНАЕУ.

\section{Перелік використаних джерел}

Anshari, B., Guan, Z. W., \& Wang, Q. Y. (2017). Modelling of Glulam beams pre-stressed by compressed wood. Composite Structures, 165 , $160-170$ https://doi.org/10.1016/i.compstruct.2017.01.028

Bredikhin, V. V. (1997). Patent RU № 2095528.

Emelianov, E. A., \& Tokmakov, A. L. (2008). Patent RU № 2198091. Grachev, V. A. (2003). Patent RU № 2198091.

Hetzer. (1906). Patent DRP № 197773.

Jogans, E. (2006). Patent DE № 059178.

Kovalchuk, L. M. (1982). Patent SU № 947349.

Nakashidze, B. V. (1986). Patent RU № 1244259.

Schneider, E. I. (1965). Patent Swiss № 3170198. 
THE STUDY OF THE PHENOMENON OF PRESTRESSED GLULAM BEAMS

For many years, prestressed glued beams have been successfully used, for example, as supporting structures in construction. Based on the analysis of recent studies of prestressed wooden beams, the aim of the research was to develop a design with a reduced consumption of materials. The technical result is achieved due to the method of manufacturing a prestressed straight wooden beam by gluing thin pre-curved lamellas to the required height, after which the glued lamella block is cut in height along the longitudinal axis and then the cut parts are glued together with each other by their curved sides (surfaces). The purpose of the experiment was to investigate the bending stiffness of a rectilinear beam glued from curved lamellae in the case when there are no preliminary stresses in the lamellae, with the case of the presence of such stresses. The first load option was to create a prestressed state of the beam and determine the maximum normal stresses. The prestressed state of the lamellae in the bent and fixed (glued) position was simulated by stretching the upper layers of each of the lamellae during their global contact. When bent, it was found that each of the lamellae has stretched areas in the upper part with tensile stress from SX $=+65 \mathrm{MPa}$ to $\mathrm{SX}=+30 \mathrm{MPa}$ and compressed regions in the lower part with compression stress from $\mathrm{SX}=-30 \mathrm{MPa}$ to $\mathrm{SX}=-80 \mathrm{MPa}$. The second variant of the load was to create a workload on the top plane of the beam in the absence of prestressing. The maximum deflection in the middle of the beam was URES $=43.47 \mathrm{~mm}$. The values of internal stresses in this case are in the range from $-82 \mathrm{MPa}$ in the compressed zone to $+82 \mathrm{MPa}$ in the stretched one. The third variant of the load consisted in the presence of both prestressing and working load. The maximum deflection in the middle of the beam was URES $=27.49 \mathrm{~mm}$. The values of internal stresses in this case are in the range from SX $=-27 \mathrm{MPa}$ in the compressed zone to SX $=+34.5 \mathrm{MPa}$ in the stretched one. The results of computational experiments show that by applying preloads, in the direction opposite to the opposite bending of the workload, we can compensate for the influence of the workload. It has been established that the application of the prestressing phenomenon enables creating structures of rectilinear glued wooden beams of reduced material consumption, while the effect of increasing the carrying capacity of a wooden beam will be limited by the compressive strength of the material it is made of.

Keywords: prestressing; glued wooden beams; reinforced wooden beams; lamellae. 